Abstracta Iranica

Revue bibliographique pour le domaine irano-aryen

Volume 32-33 | 2013

Comptes rendus des publications de 2009-2010

\title{
Rudi Matthee. The Safavids under Western Eyes: \\ Seventeenth-Century European Travelers to Iran
}

\section{Giorgio Rota}

\section{Q OpenEdition \\ 1 Journals}

\author{
Electronic version \\ URL: http://journals.openedition.org/abstractairanica/40670 \\ DOI: 10.4000/abstractairanica.40670 \\ ISSN: 1961-960X \\ Publisher: \\ CNRS (UMR 7528 Mondes iraniens et indiens), Éditions de l'IFRI \\ Printed version \\ Date of publication: 1 December 2013 \\ ISSN: 0240-8910

\section{Electronic reference} \\ Giorgio Rota, «Rudi Matthee. The Safavids under Western Eyes: Seventeenth-Century European Travelers \\ to Iran ", Abstracta Iranica [Online], Volume 32-33 | 2013, document 247, Online since 01 July 2016, \\ connection on 27 September 2020. URL : http://journals.openedition.org/abstractairanica/40670 ; \\ DOI : https://doi.org/10.4000/abstractairanica.40670
}

This text was automatically generated on 27 September 2020.

Tous droits réservés 


\title{
Rudi Matthee. The Safavids under Western Eyes: Seventeenth-Century European Travelers to Iran
}

\author{
Giorgio Rota
}

\section{REFERENCES}

Rudi Matthee. «The Safavids under Western Eyes: Seventeenth-Century European Travelers to Iran », Journal of Early Modern History, 13, 2009, p. 137-171.

1 After investigating Safavid perceptions of the West, Matthee has turned to examining the descriptions by 17th century European travelers of Safavid Persia and the potential value of these travel accounts to modern scholars. He relies on a large range of travelogues: the writings not only of the "usual suspects" (Della Valle, Olearius, Chardin and others) but also of lesser-known travelers. This confirms Matthee's close familiarity with the historical sources while lending weight to his conclusions.

Instead of following fashionable academic trends and looking for reasons to discredit foreign travelers and their accounts as "colonial" and biased, Matthee has focused on what he calls "commensurability" (p. 140), the possibility that an observer might find points in common with the observed. While these travelers inevitably carried with them "vestiges of the preceding age" (p. 142), they were no longer first and foremost Christians traveling in foreign lands (as their predecessors were in earlier times); nor were they yet the bearers of theories or feelings of racial superiority reinforced by the success of Western imperialism (like 19th- and 20th century travelers).

Matthee shows that "Westerners generally liked and felt comfortable in Iran" (p. 171). They praised the local people and customs, the security provided by the government, Persian wit and intellectual curiosity, and many other aspects, ranging from the food to the possibility to engage freely in discussions on religion - which was impossible in many parts of the Muslim world and, for that matter, of Europe. Persia and the Persians 
were generally described in more favorable terms than the Ottoman Empire and the "Turks". This was not a mere consequence of old stereotypes - Persia as a country of ancient civilization known through Classic sources and as a potential ally against the Ottomans versus the "Turks" as barbaric upstarts and mortal enemies of Christian Europe - but was confirmed by travelers' experiences, which contemporary scholars can often corroborate. The inescapable conclusion is that the best and most openminded among the 17th century travelers - and they were numerous - were willing and able to respond to Persia and its culture, despite stereotypes and limited knowledge, and "to test and even transcend the confines of their culture and its assumptions" (p. 170). Therefore, it is impossible to dismiss these travelogues and the enormous amount of information contained in them with the naive argument that "they reveal more about the observer than the observed". Also noteworthy are the remarks about the "genealogy" of 17th century European accounts of Persia (p.169). Since travelers were often familiar with the works of their predecessors and borrowed freely from them or were influenced by them, we must look at these writings "as a palimpsest rather than a series of discrete texts" (p. 169 and, too, 146, 148-149) and investigate the filiation between individual accounts.

4 The most significant and helpful parts of this contribution are the passages (p. 139-140, $147,151,158-159,170)$ where Matthee tersely and persuasively warns that the criticism of Western "Orientalism" as propounded by Edward Said and his devotees (with their dogmatic and often poorly documented assumptions about the Western traveler's biased "gaze") does not provide a valid theoretical framework or analytical tool for understanding and historically assessing European accounts of travels in Persia during the 17th century and the premodern period in general. This contribution sets an authoritative standard for future studies on the subject of the writings left by European travelers to Persia in the early modern period.

\section{AUTHORS}

GIORGIO ROTA

Institut für Iranistik, Wien 